
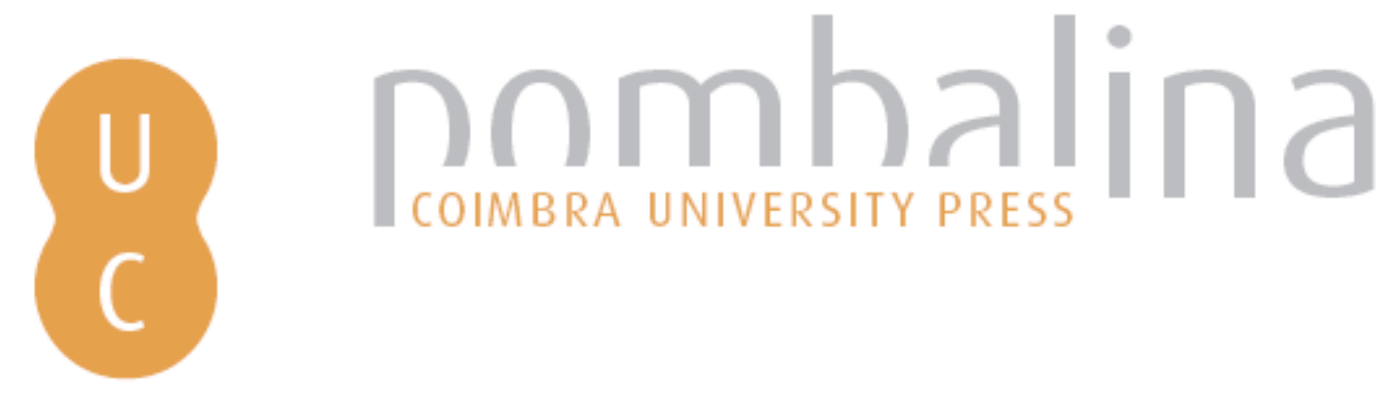

\title{
Ethanol monitoring in labour fatal accidents: an overview between 1990 and 2007 in the centre of Portugal
}

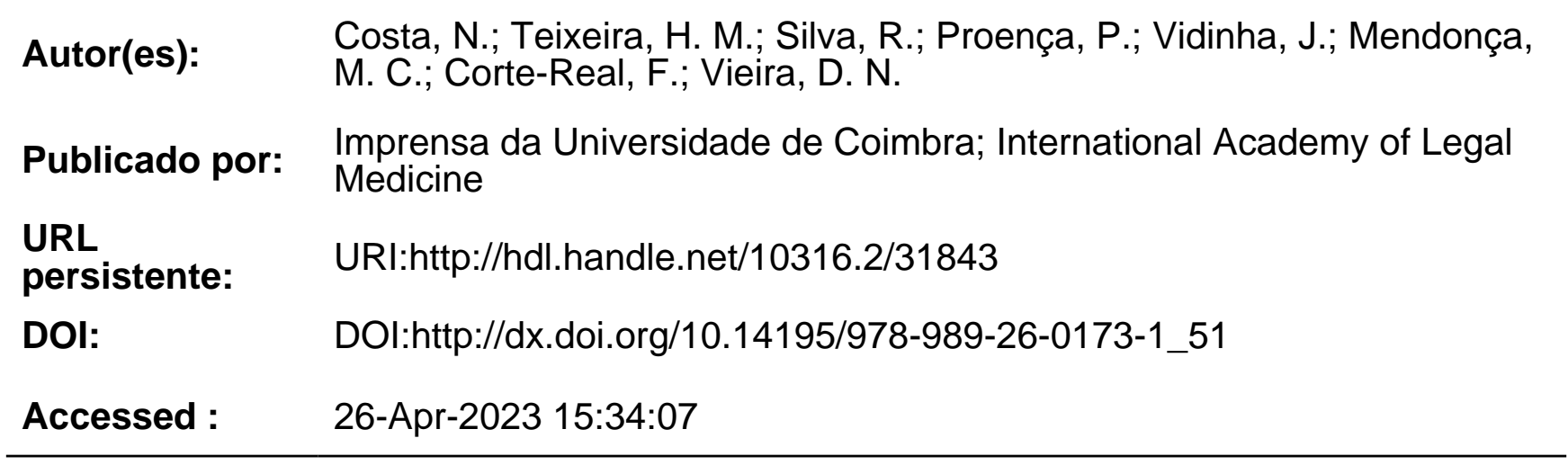

A navegação consulta e descarregamento dos títulos inseridos nas Bibliotecas Digitais UC Digitalis, UC Pombalina e UC Impactum, pressupõem a aceitação plena e sem reservas dos Termos e Condições de Uso destas Bibliotecas Digitais, disponíveis em https://digitalis.uc.pt/pt-pt/termos.

Conforme exposto nos referidos Termos e Condições de Uso, o descarregamento de títulos de acesso restrito requer uma licença válida de autorização devendo o utilizador aceder ao(s) documento(s) a partir de um endereço de IP da instituição detentora da supramencionada licença.

Ao utilizador é apenas permitido o descarregamento para uso pessoal, pelo que o emprego do(s) título(s) descarregado(s) para outro fim, designadamente comercial, carece de autorização do respetivo autor ou editor da obra.

Na medida em que todas as obras da UC Digitalis se encontram protegidas pelo Código do Direito de Autor e Direitos Conexos e demais legislação aplicável, toda a cópia, parcial ou total, deste documento, nos casos em que é legalmente admitida, deverá conter ou fazer-se acompanhar por este aviso.

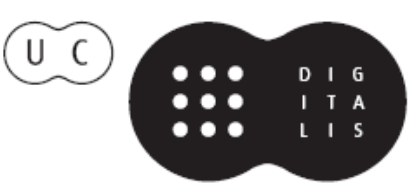




\section{Duarte Nuno Vieira Anthony Busuttil \\ Denis Cusack • Philip Beth}
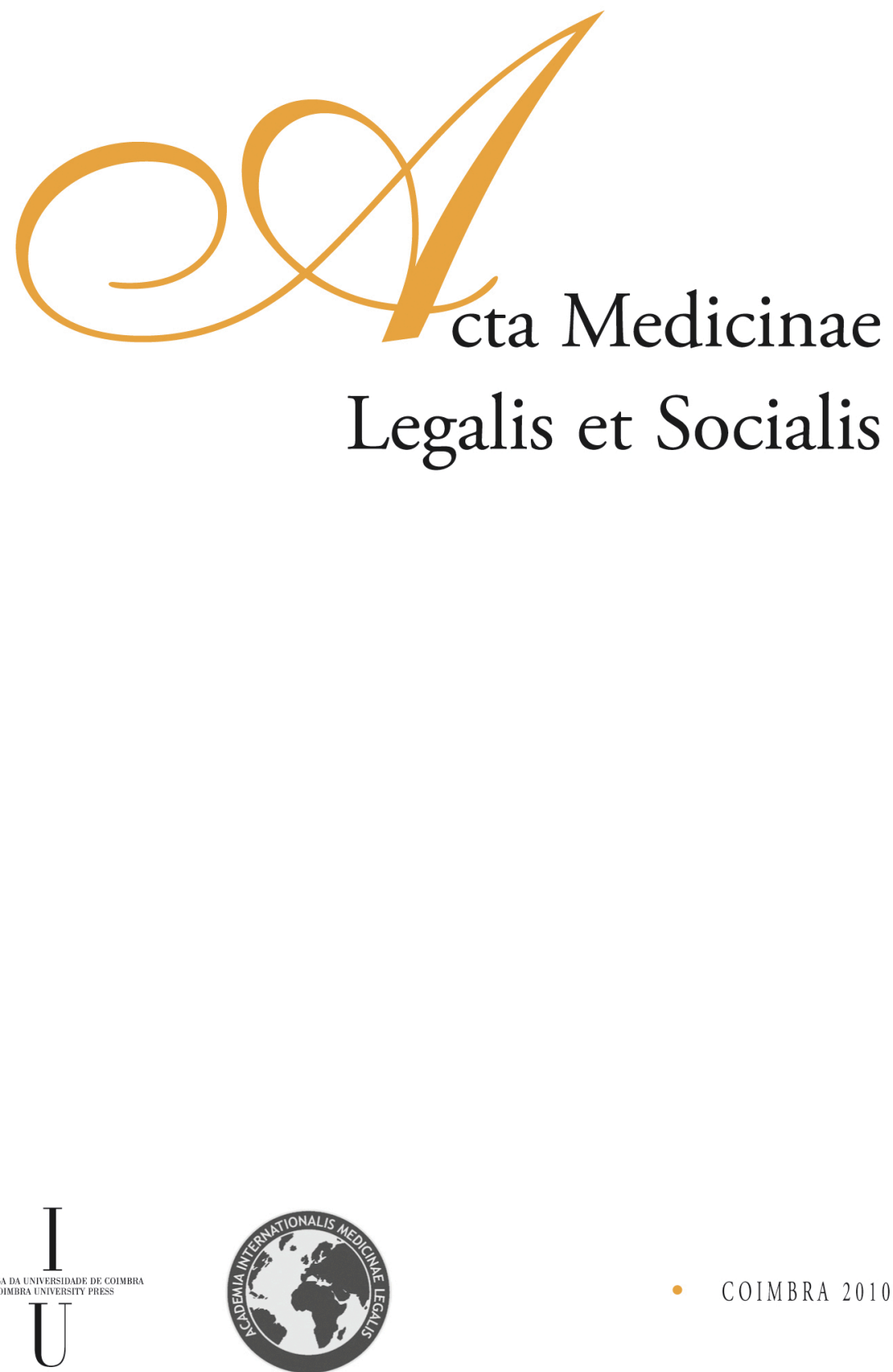
N. Costa ${ }^{2}$, H. M. Teixeira ${ }^{1,4}$, R. Silva ${ }^{3}$, P. Proença ${ }^{2}, J$. Vidinha ${ }^{2}$, M. C. Mendonça ${ }^{2,4}$, F. Corte-Real ${ }^{2,4}$, D. N. Vieira ${ }^{2,4}$

${ }^{1}$ North Branch of the National Institute of Legal Medicine, Oporto, Portugal

${ }^{2}$ Centre Branch of the National Institute of Legal Medicine, Coimbra, Portugal

${ }^{3}$ Figueira da Foz Legal Medicine Office, National Institute of Legal Medicine, Portugal

${ }^{4}$ Faculty of Medicine, University of Coimbra, Portugal

\title{
ETHANOL MONITORING IN LABOUR FATAL ACCIDENTS: AN OVERVIEW BETWEEN 1990 AND 2007 IN THE CENTRE OF PORTUGAL
}

\begin{abstract}
No much information is available on workplace drug testing, including ethanol, being this substance often implicated in labour accidental deaths. The aim of this study was to assess the presence of alcohol among in labour fatal accidents between January 1990 and December 2007, by presenting the requests and toxicological results of corresponding autopsies, from the Pathology Service of the Centre Branch of the National Institute of Legal Medicine and from a Legal Medicine Office. In the Forensic Pathology Service, between 1990 and 2007, a total of 261 autopsies were performed on labour accidents victims. Ethanol analysis was requested in only $50 \%$ of the cases, with $25 \%$ positive results. From the positive studied cases, $24 \%$ presented ethanol concentrations above $1.2 \mathrm{~g} / \mathrm{L}$ and $55 \%$ under $0.5 \mathrm{~g} / \mathrm{L}$, with all the cases related to men aged between 41 and 50 years-old (24\%). In the Legal Medicine Office, from April 2001 to 2007, 1219 autopsies were performed, 28 to labour victims, with only one female victim. Ethanol analysis was requested in $75 \%$ of the cases, with $48 \%$ positive results, $70 \%$ under $0.5 \mathrm{~g} / \mathrm{L}$, with all the cases related to men aged between 51 and 60 years-old (24\%).
\end{abstract}

Keywords: Ethanol; labour accidents.

\section{Introduction}

According to WHO, approximately $10-30 \%$ of work accidents would be alcohol related. Alcoholic beverages at workplace may produce an even remarkable increase of direct risks, because of psychophysical alteration and indirect risks produced by added effect of alcoholic beverages with industrial toxic substances. Even with low alcohol rates, the reaction time becomes longer, error frequency in response to visual or hearing stimulations is higher and hence the risk of accidents becomes sensible. Besides, alcoholrelated working performance problems may be caused not only by drinking at work but also by drinking a lot of alcoholic beverages outside working time [1].

Alcoholism is a growing medical and public health issue both in adult and in younger populations. It is a multi-aetiological phenomenon influenced by genetic, psychological, cultural and other factors. Alcoholic beverages have traditionally been prepared from various ingredients, such as grapes, malt, and rice. Drinking prevalence has varied and is more pronounced in women and the youth. Alcoholism is shown to be of neurophysiologic origin and may lead to the impairment of all human 
body systems. The most frequent cause of death in alcoholics is the diseases of the cardiovascular system [2].

Fatal accidents in the workplace can be caused by work conditions, aggravation of a chronic disease or alcohol intoxication [3].

\section{Material and Methods}

This study has been carried out by the National Institute of Legal Medicine of Portugal. The target population consisted of individuals killed in labour accidents. The data available in each case was: year, sex, age and alcohol concentrations.

The authors present the requests and consequent alcohol results of autopsies performed on fatal victims of labour accidents from 1990 and 2007 in the Pathology Service of the Centre Branch of the National Institute of Legal Medicine (NILM) and performed from April 2001 (open date of the office) and 2007 in the Legal Medicine Office of Figueira da Foz (LMO). All alcohol analyses were performed in the Forensic Toxicology Laboratory of the Centre Branch of the NILM.

Several variables were studied and all the pertinent data was registered, separated and statistically treated with the SPSS program (Statistical Package will be Social Sciences).

\section{Results and Discussion}

As mentioned above, the main objective of our work was the analysis of all labour accident cases from autopsies performed in the Forensic Pathology Service of the Centre Branch of the National Institute of Legal Medicine (NILM) between 1990 and 2007 and performed from April 2001 and 2007 in the Legal Medicine Office of Figueira da Foz (LMO), in order to know the prevalence of alcohol in this cause of death.

It is important to be aware that there is no published data in Portugal, any work that could allow us to make any comparison with the results now obtained, and the results will be discussed based on a vision of our system and medical-legal reality.

Analyzing the cases performed in the Centre Branch, it can be observed that they do not differ significantly in the $90^{\text {th }}$ decade, with about $55 \%$ of cases, compared to the 2000 s with about $45 \%$. Of all the cases analysed, we found that the vast majority were related to build construction, as also referenced by other authors [4].

In fact, we can assume that this can be explained within the framework of civil protection workers, as there is a greater awareness and obligation for the employer to address the risks inherent in the employee's tasks [5]. Examples include the construction workers, where it is required to obey certain security measures, such as the placement of security barriers in order to avoid possible precipitation, among other important and effective measures, such as compulsory use of helmets for protection, thus contributing to an improvement in working conditions in order to prevent possible this kind of fatal accidents [6]. The years 1994 and 2002 presented the highest number of cases, 22 cases each, accounting for $8.4 \%$ of the total analyzed.

Analysing the years 2000s in the Centre Branch, we observe that since 2003 the number of accidents decreased, excepted in 2007 with a very high percentage eventually 
explained by the possible association of fatigue felt when working consecutively, sometimes more than 40 hours per week, and this behaviour can be the basis for many of these accidents and the possible association of alcohol and other substances, known to disrupt the dexterity necessary to perform their functions. In the LMO, the opposite is true, because despite a sharp increase in the number of accidents over the years, reaching its peak in 2006 with 8 cases (28.6\%), there is a decrease in 2007 with only 1 case $(3.6 \%)$, which may possibly be explained by the fact that Figueira da Foz is a smaller area and does not cover as many villages as the area covered by the Branch, where security measures are properly implemented.

In the Forensic Pathology Service, a total of 9409 autopsies were performed between 1990 and 2007, 261 on labour accidents victims, 97\% in male victims (Fig.1), aged from 41 to 50 years-old. The number of cases in males can be explained by the fact that men are closely linked to the performance of heavy work, which, by their nature entails more health risk [4,6]. Presently, there is a behaviour changing, since there have been an increasing number of women workers, particularly in professions that were previously male safeguards, such as in petrol stations, driving taxis and even industrial.

In the Forensic Pathology Service, ethanol analysis was requested in only $50 \%$ of the cases, with $25 \%$ positive results (Fig. 2). But it is important to sate that these numbers correspond to 18 years analyzed.

In the Legal Medicine Office, from April 2001 to 2007, 1219 autopsies were performed, 28 to labour victims, aged from 61 to 70 years-old, with only one female victim (Fig.4).

The labour capability for certain works depend on the individual ability to perform each task being, sometimes, the age a very important and conditioning factor for accident risk.

In the Centre Branch, only $50 \%$ of the labour fatal accident cases included ethanol request analysis. In fact, with regard to the years in which this determination was not required, there was a clear predominance in the years 1990, 2001, 2005 and 2006. There was, however, an increase in this request as we move forward in time, too pronounced in the 2000s. In the LMO, we observed, over the years studied, an increase in the requests, and in 2007 almost all cases included the request of this psychotropic substance.

Of the positive cases analyzed, we observed that the majority of the cases were well below $0.5 \mathrm{~g} / \mathrm{L}$, the minimum legal limit allowed by law, with $13.7 \%$ (18 cases) for the Brach and 28.6\% (6 cases) for the LMO (Fig. 3-6).

Analyzing the cases in this $\mathrm{BAC}(\mathrm{BAC} \leq 0.5 \mathrm{~g} / \mathrm{L})$, there has been a regular consumption through each year, with a predominance in March, in the Branch, and a regular consumption over the months in the LMO, highlighting again the male gender, with about $55 \%$ of the cases in the Branch and about $80 \%$ of cases in the office. The most incident group was aged between 51 and 60 years in the Branch, and aged between 31 and 50 and between 61 and 70 years-old in the office, with about $30 \%$ of the cases in both.

Portuguese law concerning labour monitoring significantly addresses the problem of alcohol and psychotropic substances, because workers can, by law, be subject to a random check by the employer at any time of their activity. However, its review or determination in postmortem cases is not fully informed or legislated, in relation to how 
to act specifically in labour accident autopsies. Accordingly, the discrepancy of results concerns the practice carried out by experts who, more and more, are being aware and scientifically instructed to further research and evaluation of substance influence in labour accidents and consequent legal aspects implicated, such as life insurance, for example.

\section{Conclusion}

From the casuistic study performed it is possible to observe that over the years the pathologists increased the number of requests to alcohol in labour victims in order to better explain and/or interpret the presence of this substance and its possible interaction with psychomotor skills required in several activities.

As stated by some authors [2] alcoholism at workplace is a very important issue as it affects health, reduces productivity, and may lead to accidents, injuries and decreased working capacity. Alcohol-related difficulties develop much earlier than the clinical picture. The diagnosis of alcoholism includes early detection of alcoholrelated problems, so it is necessary to orient the healthcare services towards primary prevention and early intervention.

Many studies have shown the role of alcohol intake, even in low quantities, as a risk factor in accidents, mainly road accidents, but also in accidents occurring in the home and at the workplace. For a blood alcohol level of $0.5 \mathrm{~g}$ per litre, the risk of accident is already two-fold. Accidents occur more often to persons who drink occasionally than to those who are alcohol-dependent. For a subject of average body weight, it is accepted that one glass of an alcohol-containing drink can raise the blood alcohol level by approximately $0.2 \mathrm{~g}$ per litre. One to two hours is required to eliminate this quantity of alcohol [6].

\section{References}

1. PERSECHINO B, IAVICOLI S. Work and alcohol abuse: the issues. G Ital Med Lav Ergon. 29 (3 Suppl): 510-513, 2007.

2. ZUSKIN E, JUKIĆ V, LIPOZENCIĆ J, MATOSIĆ A, MUSTAJBEGOVIĆ J, TURCIĆ N, POPLASEN-ORLOVAC D, BUBAS M, PROHIĆ A. Alcoholism: how it affects health and working capacity. Arh Hig Rada Toksikol, 57(4): 413-426, 2006.

3. RYGOL K, KABIESZ-NENICZKA S, OLSZOWY Z. Accidents in the workplace caused by alcohol intoxication. Arch Med Sadowej Kryminol., 54(4): 234-241, 2004.

4. MAEDA, H., FUJITA M.Q., ZHU B.L., QUAN L., KAMIKODAI Y, TSUDA K., TANIGUCHI M. (2003). Labor-related fatalities in forensic postmortem investigations during the past 6 years in the southern half of Osaka city and surrounding areas. Legal Med.; 5 Suppl 1: S325-7.

5. AlHaiqUE, D. (2000). Aging and occupational accidents. Med Lav. 2000 JulAug;91(4):403-17.

6. HOWARD, G. (1990). Alcoholism and drug abuse--some legal issues for employers. Brit. J. Addic.;85(5):593-603.

7. DALLY S. Acute alcoholic intoxication and accidents. Rev Prat, 43(16): 2071-2074, 1993. 


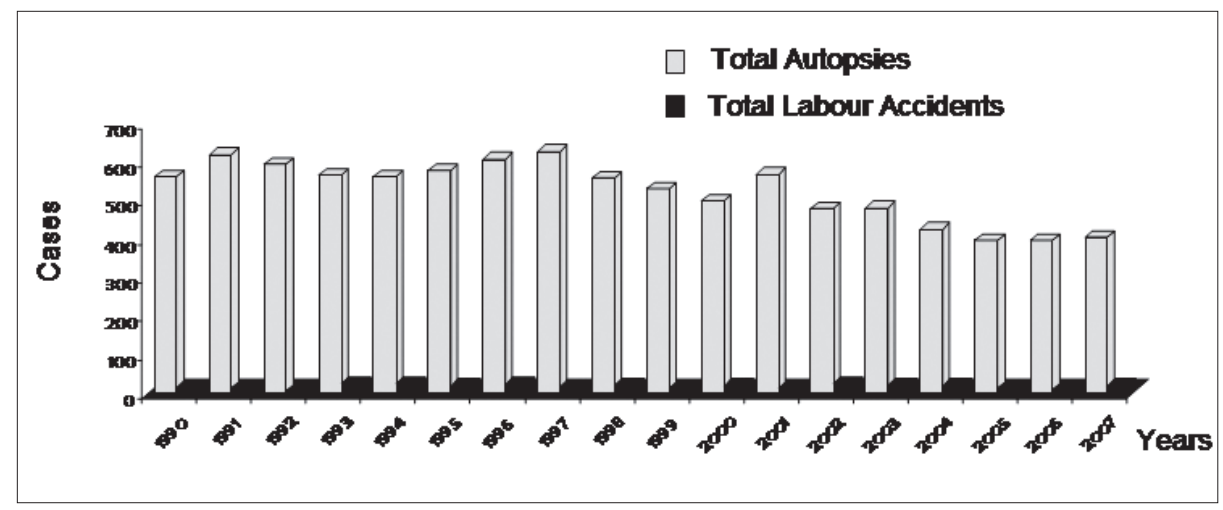

Figure 1 - Number of labour Accidents in the autopsies performed in the forensic pathology service between 1990 and 2007.

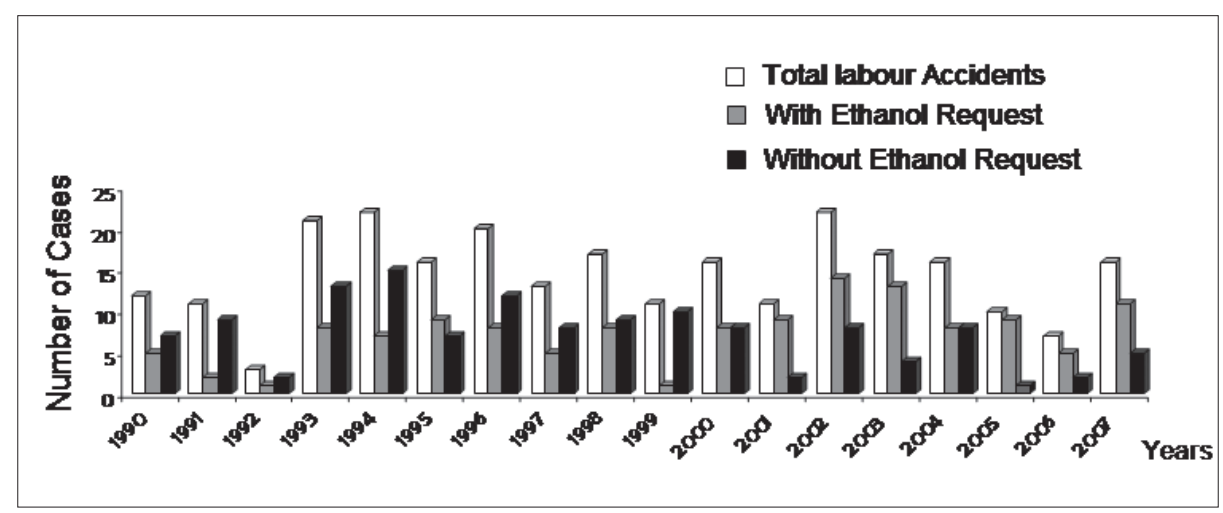

Figure 2 - Number of Labour Accidents without Ethanol request (in the forensic pathology service).

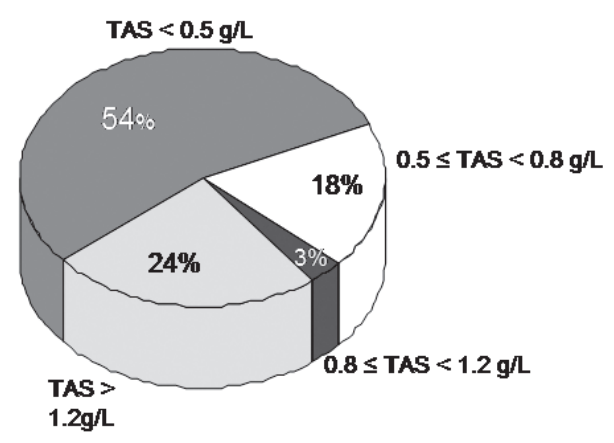

Figure 3 - Positive Ethanol Results distribution (in the forensic pathology service). 


\section{Total Autopsies}

Total Labour Accidents

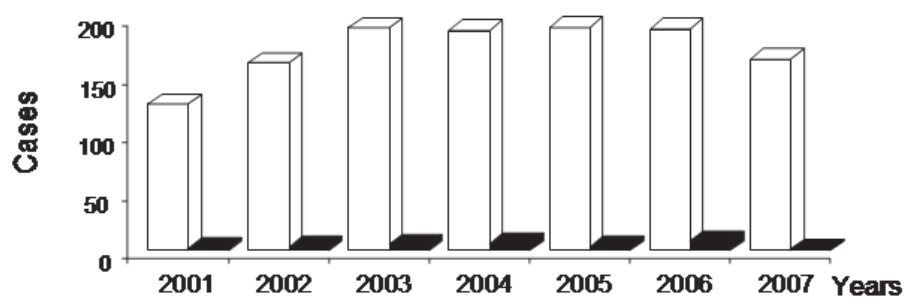

Figure 4 - Number of labour Accidents in the autopsies performed in the Legal Medicine Office (Figueira da Foz) between 2001 and 2007.

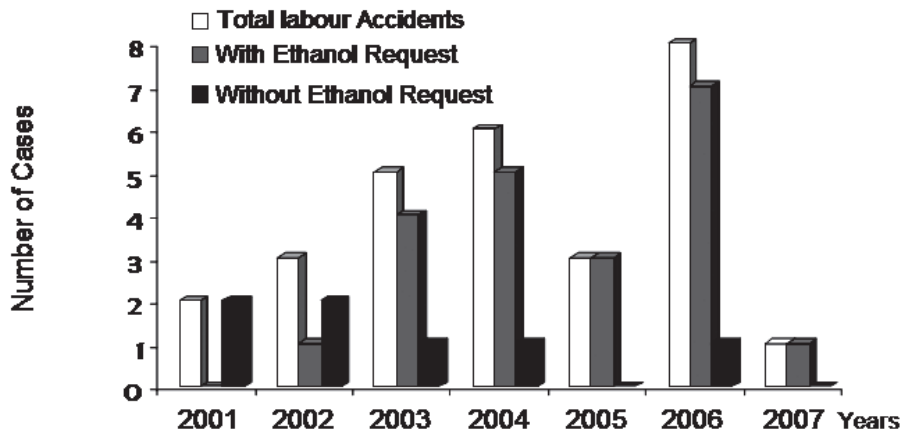

Figure 5 - Number of Labour Accidents without Ethanol request (in the Legal Medicine Office of Figueira da Foz).

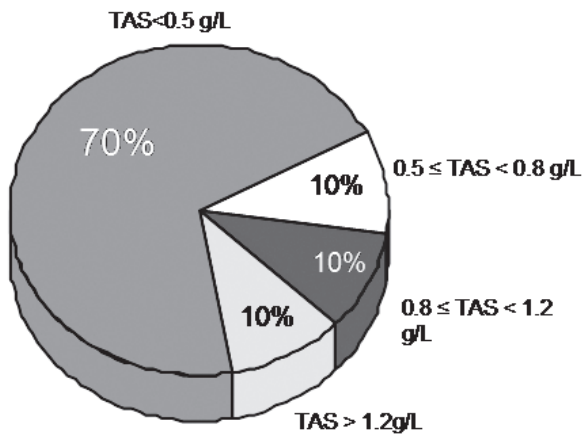

Figure 6 - Positive Ethanol Results distribution (in the Legal Medicine Office of Figueira da Foz). 


\begin{tabular}{|c|c|c|}
\hline Age & Male & Femalle \\
\hline$<1$ & 0 & 0 \\
\hline $1-10$ & 0 & 0 \\
\hline $11-20$ & 11 & 0 \\
\hline $21-30$ & 16 & 2 \\
\hline $31-40$ & 27 & 0 \\
\hline $41-50$ & 35 & 1 \\
\hline $51-60$ & 25 & 0 \\
\hline $61-70$ & 11 & 0 \\
\hline $71-80$ & 3 & 0 \\
\hline $81-90$ & 0 & 0 \\
\hline$>90$ & 0 & 0 \\
\hline TOTAL & 128 & 3 \\
\hline$\%$ & 97.71 & 2.29 \\
\hline
\end{tabular}

Table 1 - Positive results distribution per gender/age (in the forensic pathology service).

\begin{tabular}{|c|c|c|}
\hline Age & Male & Female \\
\hline$<1$ & 0 & 0 \\
\hline $1-10$ & 0 & 0 \\
\hline $11-20$ & 0 & 0 \\
\hline $21-30$ & 0 & 0 \\
\hline $31-40$ & 0 & 0 \\
\hline $41-50$ & 2 & 0 \\
\hline $51-60$ & 3 & 0 \\
\hline $61-70$ & 2 & 0 \\
\hline $71-80$ & 3 & 0 \\
\hline $81-90$ & 0 & 0 \\
\hline$>90$ & 0 & 0 \\
\hline TOTAL & 10 & 0 \\
\hline$\%$ & 100 & 0 \\
\hline
\end{tabular}

Table 2 - Positive results distribution per gender/age (in the Legal Medicine Office of Figueira da Foz). 